
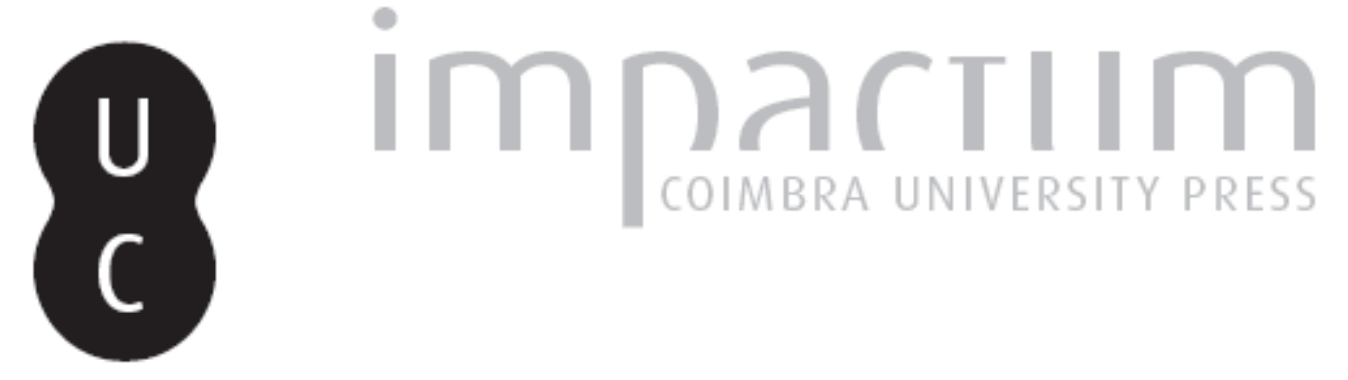

\title{
Gestos e fragmentos: (A questão da «morte de Deus» em Sartre)
}

Autor(es): Pita, António Pedro

Publicado por: Imprensa da Universidade de Coimbra

URL persistente:

URI:http://hdl.handle.net/10316.2/45333

DOI:

DOI:https://doi.org/10.14195/2183-8925_9-3_7

Accessed : $\quad$ 26-Apr-2023 11:23:54

A navegação consulta e descarregamento dos títulos inseridos nas Bibliotecas Digitais UC Digitalis, UC Pombalina e UC Impactum, pressupõem a aceitação plena e sem reservas dos Termos e Condições de Uso destas Bibliotecas Digitais, disponíveis em https://digitalis.uc.pt/pt-pt/termos.

Conforme exposto nos referidos Termos e Condições de Uso, o descarregamento de títulos de acesso restrito requer uma licença válida de autorização devendo o utilizador aceder ao(s) documento(s) a partir de um endereço de IP da instituição detentora da supramencionada licença.

Ao utilizador é apenas permitido o descarregamento para uso pessoal, pelo que o emprego do(s) título(s) descarregado(s) para outro fim, designadamente comercial, carece de autorização do respetivo autor ou editor da obra.

Na medida em que todas as obras da UC Digitalis se encontram protegidas pelo Código do Direito de Autor e Direitos Conexos e demais legislação aplicável, toda a cópia, parcial ou total, deste documento, nos casos em que é legalmente admitida, deverá conter ou fazer-se acompanhar por este aviso.

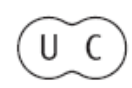




\section{REVISTA DE HISTÓRIA DAS IDEIAS 9}

\section{O SAGRADO E O PROFANO ***}

HOMENAGEM A J. S. DA SILVA DIAS

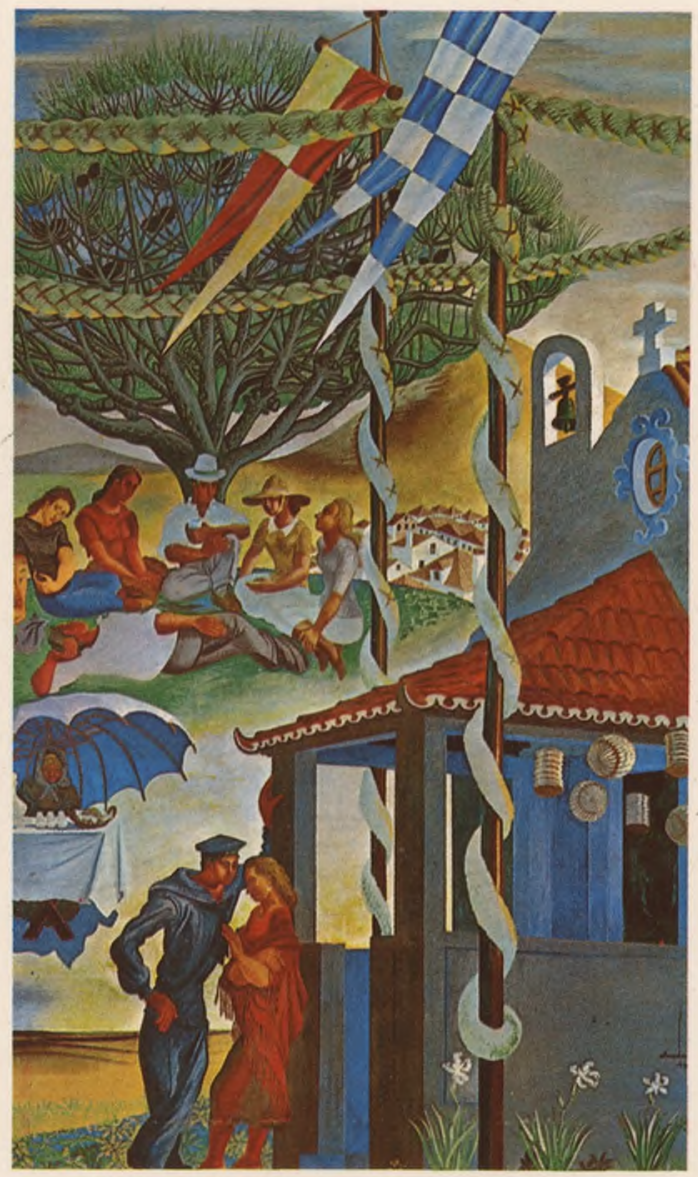

INSTITUTO DE HISTÓRIA E TEORIA DAS IDEIAS FACULDADE DE LETRAS 


\section{GESTOS \& FRAGMENTOS **}

\section{(A questão da «morte de Deus» em Sartre)}

\section{Consequências da «morte de Deus»}

L'Être et le Néant é colocado, por Sartre, logo nas primeiras páginas, na consequência de Nietzsche:

«Se nos desembaraçamos de vez do que Nietzsche chamava a ilusão dos além-mundos e se já não cremos no ser por-trás-da-aparição, esta torna-se, pelo contrário, plena positividade, a sua essência é um «parecer» que já não se opõe ao ser mas que, pelo contrário, é a sua medida. Porque o ser de um existente é precisamente o que ele parece» $\mathrm{O})$.

Trata-se de uma consequência que se pretende ateia: fica a plena positividade da aparição, ou fenómeno, mas ter-se-á perdido o que ligava as aparições ou fenómenos e tornava o mundo uma totalidade. Que as coisas sejam somente aquilo que são e que sejam o que oferecem a um olhar aue as

* Faculdade de Letras da Universidade de Coimbra.

** As páginas que se seguem pertencem a um trabalho mais amplo, subordinado ao tema Intencionalidade e primado do olhar em "O ser e o nada» de Jean-Paul Sartre, no qual, através da doutrina sartriana sobre o olhar (nos seus pressupostos e nas suas implicações), tento captar o limite interno da metafísica como pensamento do desvelamento puro. Para, depois, erguer a pergunta acerca das condições e da fecundidade do pensar - e exercer - o discurso filosófico não no interior dessa lógica, constituída a partir do primado do Um, mas tomando o discurso filosófico à letra: como escrita: como escrita a duas mãos.

Creio não ser infiel ao eco mais vivo que o magistério do Prof. Doutor José Sebastião da Silva Dias em mim produziu, publicando, em sua homenagem, algumas páginas que são o provisório ponto de partida (mas «a ciểncia é um longo errar e aprender») * de 


\section{O Sagrado e o Profano}

capte - denuncia exclusivamente por intermédio de urna crise relacional a crise da ideia de todo.

As coisas ficam pois entregues solitariamente a si mesmas, numa nudez irredutível — pedra, arbusto, «a lanterna, a paliçada e o céu» $\left({ }^{2}\right)$. Deserto.

A morte de Deus, que lemos na passagem transcrita, implica a desertificação do mundo; a morte de Deus («cultivar o deserto/como um pomar às avessas») faz entrar em crise uma ideia de mundo («então nada mais/destila; evapora;/onde foi maçã/resta uma fome») porque rompe as relações entre as coisas; o que se cria totalidade é, afinal, coisas; desfeita a plenitude do mundo, resta a opacidade das coisas e o intervalo entre elas. A morte de Deus implica para Sartre a evidência de que o «mundo é um reino de buracos» ( $\left.{ }^{3}\right)$, a revelação de um esvaziamento («onde foi palavra/(potros ou touros/contidos)/resta a severa forma do vazio») $\left({ }^{4}\right)$.

É essa «solidão das coisas» que Sartre retira da ausência de Deus: «a ausência de Deus devia ler-se por todo o lado. As coisas estavam sós e sobretudo o homem estava só» $\left(^{\circ}\right)$.

Os homens são irredutivelmente singulares, uns, e a sua natureza não ostenta outra assinatura senão a sua: «Deus poderia ter-me livrado do apuro: eu seria uma obra assinada» $\left({ }^{6}\right)$. Enquanto obra sua, seria certamente precedido por um plano, por um sonho de futuro, pela atribuição de um destino. Teria um criador — por isso, ocuparia um lugar no conceito universal.

Em Les mots, Deus é o olhar absoluto para o qual tudo (todos) é objecto e que, pelo seu carácter totalizador, trans-

uma reflexão que sinto ainda desesperadamente inacabada (mas «a ciência é também paciência - e os pretensiosos ou apressados não nasceram para ela») **.

Aqui ficam: sem mais palavras. Porque, ficarem, é já o mais que não é preciso explicitar.

* J. S. da Silva Dias, Os Descobrimentos e a problemática cultural do século XVI, Coimbra, 1973, p. XIII.

** Idem, A política cultural da época de D. João 111, vol. I, t. 1, Coimbra, 1969. p. XIV.

0) Jean-Paul Sartre, L'être et le néant, Paris, 1943, p. 12. Utilizarei a sigla: E.N.

(2) Idem, La nausée, Paris, 1938, p. 16. Utilizarei a sigla: N.

(3) Idem, Cahiers de la drôle de guerre, Paris, 1983, p. 146. Utilizarei a sigla: C.G.

(4) João Cabral de Melo Neto, Poesias completas, Rio de Janeiro, 1979, pp. 331-332. 1982 , p. 547.

$\left(^{5}\right)$ Simone de Beauvoir, La cérémonie des adieux Paris

(6) J.-P. Sartre, Les mots, Paris, 1964, p. 78. Utilizarei a sigla: M. 


\section{Gestos \& Fragmentos}

forma os seus objectos em totalidade. A passagem transcreve-se, apesar de muito célebre:

«Brincava com fósforos e queimara um pequeno tapete; estava eu a dissimular o meu crime quando, de súbito, Deus me viu, senti o seu olhar dentro da minha cabeça e sobre as minhas mãos; eu rodopiava na casa de banho, horrivelmente visível, um alvo vivo. A indignação salvou-me: enfureci-me contra 'cão grosseira indiscrição, blasfemei, murmurei como meu Avố: 'maldito nome de Deus, nome de Deus, nome de Deus'. Nunca mais ele me contemplou» $\left({ }^{7}\right)$.

pode ler-se:

Numa nota de 1 de Dezembro de 1939, por seu lado,

«Não tenho nenhumas recordações religiosas: todavia, estou a ver-me aos sete ou oito anos, na Rue Le Goff, a queimar as cortinas de tule da janela com um fósforo, e esta recordação está ligada a Nosso Senhor, não sei porquê. Talvez porque esse facto incendiário não tivesse tido nenhuma testemunha e no entanto eu tivesse pensado: 'Nosso Senhor está a ver-me'» $\left({ }^{8}\right)$.

Se o olhar do outro é uma mediação indispensável do $\mathrm{Eu}$ consigo próprio, como adiante veremos melhor, («O que eu capto imediatamente quando ouço quebrarem-se ramos por trás de mim, não é que há alguém, é que sou vulnerável, que tenho um corpo que pode ser ferido, que ocupo um lugar e que não posso, em caso nenhum, evadir-me do espaço em que estou sem defesa, em suma, que sou visto. Deste modo, o olhar é primeiro um intermediário que reenvia de mim a mim-mesmo») ( ${ }^{9}$ ), a crise do olhar de Deus á a crise da mediação absoluta: a verdade da fenomenología conjuga-se, assim, internamente, com a consequência da morte de Deus: «O pensamento moderno realizou um progresso considerável reduzindo o existente à série das aparições que o manifestam» (10), «mas se nós nos libertámos de vez do que Nietzsche chamava a ‘ilusão dos além-mundos' e se já não cremos no ser-por-trás-da-aparição, esta torna-se, pelo contrário, plena positividade, a sua essência é um parecer que não se opõe ao ser mas que é a sua medida, pelo contrário. Porque o ser de um existente

(7) M., p. 83 .

(8) C.G., p. 93

(9) E.N., p. 305.

(10) E.N., p. 11. 
é precisamente o que ele parece» $\left({ }^{1 \mathrm{X}}\right)$; «a aparência não esconde a essência, ela revela-a: é a essência» (12).

O olhar de Deus, totalizador, definitivamente objectivador, jamais admitirá que o seu objecto seja outro; e, por outro lado, é um olhar inacessível a outro olhar que não é por sua vez olhável, é um fundamento absoluto de uma situação de dependência.

É a evidência com que a inexistência de Deus é admitida no discurso sartriano que interessa, por agora, reter. Não tanto o problema da inexistência de Deus, da sua fundamentação e dos problemas que implica — vulgarmente sublinhado em alguma bibliografia — mas o facto de uma linha da sua filosofia constituir a fundamentação de uma evidência que a precede e que só é sustentada pela sua própria verdade (13). Só deste modo podemos 1er, sem comentários desadequados, considerações como estas:

«eis que, um dia, em La Rochelle, quando esperava as meninas Machado que me acompanhavam de manhã quando eu ia para o Liceu, impacientei-me com o seu atraso e, para ocupar o tempo, pus-me a pensar em Deus. 'Rem', disse para comigo, 'ele não existe'. Foi uma autêntica evidência, embora já nem sequer me recorde em que é que ela se baseava. E depois acabou-se, nunca mais pensei nisso, não me preocupei com esse Deus muito mais do que me havia preocupado com o Deus vivo. Creio que seria difícil encontrar uma natureza menos religiosa do que a minha. Resolvi a questão de uma vez por todas aos doze anos» $\left({ }^{14}\right)$.

Mais tarde esclarecerá:

«Para mim, Deus estava morto: família dividida entre o protestantismo e o catolicismo, logo contestação de um pelo outro. Já não cria senão por tradição, para agradar à minha família» $\left({ }^{15}\right)$.

Por isso, no início da sua carreira filosófica Sartre dirá estar «absolutamente seguro da não existência de Deus» (16). Recorde-se a propósito este brevíssimo diálogo de 1951: «Está

(11) E.N., p. 12.

(12) E.N., p. 12

(13) Henry Paissac, Le dieu de Sartre, Grenoble, 1950; M. Franklin da Costa, «O problema de Deus em Jean-Paul Sartre», Revista Portuguesa de Filosofia, vol. XXVI, 1970, pp. 285-312.

(14) C.G., p. 94.

(15) François Jeanson, Sartre dans sa vie, Paris, 1974, p. 21.

(16) S. Beauvoir, La cérémonie des adieux, p. 545. 


\section{Gestos \& Fragmentos}

seguro de que Deus não existe? - Tenho a convicção disso. - A convicção ou a certeza? - A certeza. Nasci numa família semi-protestante, semi-católica. Perante as contestações, desde a idade de doze anos, a minha convicção fez-se. E aí se soldaram reflexões que fizeram uma certeza» $\left({ }^{17}\right)$.

É no trilho desta evidência, ou desta certeza, que Sartre quer fazer filosofia, uma filosofia que desse conta «do meu objecto, meu' no sentido humano, quer dizer, vosso objecto também, o objecto de homem. Quer dizer, o seu próprio 'pertence-me', no e fora do mundo, e o mundo sem Deus» $\left({ }^{18}\right)$.

A tarefa assumia a seus olhos uma singularidade essencial: «todos os grandes filósofos são mais ou menos crentes». A morte de Deus não assegura, por si só, a subversão do espaço teológico. Embora Sartre não tenha pensado radicalmente esta consequência — a morte de Deus resolve-se nele em humanismo teórico - o certo é que encontra tangencialmente este problema («Deus morreu, mas o teólogo subsistia») mas para o situar, de imediato, num contexto completamente diferente: «É por isso que eu considero o ateísmo como uma conquista permanente. Um processo de laicização progressiva» (19) ou um empreendimeno cruel: «o ateísmo é um empreendimento cruel e de longo fôlego: creio tê-lo levado até ao fim» $\left({ }^{20}\right)$. Como se confessasse que não é possível ocupar, de uma só vez, o lugar do ateísmo e que ao ateu compete ir desconstruindo a convicção religiosa, residindo o ateísmo precisamente neste processo de desconstrução. Como se confessasse que o seu programa de construção de uma autonomia total se acha internamente limitado ou que a autonomia reside numa conquista permanente de esferas, cada vez mais largas, de auto-determinação.

É ainda a partir desta questão que Sartre perspectiva o testemunho de André Gide:

«o que Gide nos oferece de mais precioso, é a sua decisão de viver até ao fím a agonia e a morte de Deus. Ele tinha podido, como tantos outros, apostar em conceitos, decidir aos vinte anos da sua fé ou do seu ateísmo, e aterre a isso toda a vida. Em lugar disso, quis experimentar a sua religião, e a dialéctica viva que o conduzia ao seu ateísmo final é um percurso que pode refazer-se depois dele, mas não fixar-se por conceitos e por noções. Gide

(17) F. Jeanson, Sartre dans sa vie, p. 280.

(18) S. Beauvoir, La cérémonie des adieux, p. 280.

(19) Idem, ibidem, p. 21.

(20) M., pp. 210-211. 


\section{O Sagrado e o Profano}

é um exemplo insubstituível porque escolheu.... tornar-se a sua verdade. Decidido abstractamente aos vinte anos, o seu ateísmo seria falso; lentamente conquis ¿ado, cor oamento de um trabalho de meio^século este ateísmo torna-se a sua verdade concreta e a nossa» $\left({ }^{21}\right)$.

Por outro lado, Sartre sente-se na necessidade de assinalar a diferença entre a sua concepção e a concepção vulgar de ateísmo; fá-lo em termos altamente significativos: «guardei no dominio da moral urna única coisa da existência de Deus, o Bern e o Mal como absolutos». E depois acrescenta:

«A consequência vulgar do ateísmo é a supressão do Bem e do Mal, como absolutos, é um certo relativismo, é por exemplo a consideração de morais variáveis segundo os pontos da terra em que se encontram» $\left({ }^{22}\right)$.

Este passo, em que sugere uma transição de Deus para a existência da moral, em que se afirma a moral como um resto da existência divina, em que se afirma, afinal, que Deus sobrevive na consideração do Bem e do Mal como absolutos, deve por isso aproximar-se desta outra observação:

«não sou isento de moralismo e.... muitas vezes o moralisme tem origem na religião. Mas isso não se passou comigo. Aliás, fui educado por pais e por professores que, na sua maior parte, haviam sido campeões da moral laica e tentado sempre sobrepô-la à moral religiosa» $\left({ }^{23}\right)$.

Apesar desta restrição, há matéria suficiente para concluir que Sartre está longe da radicalidade nietzscheana de que se reivindica. Quando afirma, por exemplo, que a consequência vulgar do ateísmo é a supressão do Bem e do Mal como absolutos. Escreve:

«considero que a moral e a actividade moral do homem é como um absoluto no relativo. Há o relativo, que aliás não é todo o homem, mas que é o homem no mundo com os seus problemas no inferior do mundo. E depois há o absoluto que é a decisão que ele toma, tocando outros homens a propósito destes problemas, que é portanto um absoluto que nasce dela na medida em que os problemas que ele se põe são reladvos. Considero, portanto, o absoluto como um produto do relativo, ao contrário do que se faz vulgarmente» $(24)$.

(21) F. Jeanson, Sartre dans sa vie, p. 271.

(22) S. Beauvoir, La cérémonie des adieux, p. 551.

(23) C.G., pp. 74-95.

(24) S. Beauvoir, La cérémonie des adieux, p. 552. 
Sartre quer libertar as condutas individuais do puro relativismo sem cair no formalismo kantiano: «a moral kantiana, formal, neglicencia os dados contingentes» (25). Absoluto traduz a espessura da escolha, a sua homogeneidade, a sua identidade sem brechas.

Digamos que não é sem problemas que o leitor depara com toda esta terminologia. De facto, perpassa por toda ela uma flutuação profundamente significativa entre duas fórmulas: Deus não existe e Deus $\hat{e}$ aquele que precisa de ser negado. A apresentação do ateísmo como uma conquista permanente, um processo de laicização progressiva, um empreendimento cruel e de longo fôlego, conjugada com a dificuldade histórica de uma filosofia ateia, situa-nos numa perspectivação do problema irredutível à simples experiência originária da in-existência de Deus. Embora, em UÊtre et le Néant, Sartre queira fundamentar a impossibilidade ontológica e lógica de Deus, a verdade é que o reaparecimento do problema, mesmo sob a forma da negação, talvez mostre que se não trata de uma questão resolvida. Recolhamos, pois, a hipótese de Jeanson:

\begin{abstract}
«Sartre é um homem de fé, que não deixa de se bater contra as diversas crenças nas quais tende a investir-se, sucessivamen;e a sua exigência mais radical. Ora toda a crença é pressuposição do Absoluto; a fé. pelo contrário, quer-se absoluta no plano do seu próprio risco, da sua aposta, do seu compromisso: quer dizer na sua própria maneira de assumir o relativo. Deste modo, o crente abandona-se a um relativismo sem saída; uma crença quer uma ou:ra, cada uma referindo-se em conjunto ao Incomunicável, ao Inefável, ao Indizível dos teólogos. O homem de fé, ao contrário, só se compromete radicalmente para se pôr radicalmente à prova dos outros e do acontecimento: a sua convicção é relativamence absoluta, pois ele põe aí o próprio sentido da sua existência; mas ela é absolutamente relativa pois ele escolheu ao mesmo tempo medir a verdade pelo seu próprio poder de a fazer advir. A crença e presunção de verdade; a fé é exigência de sentido. O crente de termina-se contra a descrença ou as outras crenças; o homem de fé só pode assegurar-se da sua fé reconhecendo-a praticamente na exigência radical de qualquer homem» $\left({ }^{26}\right)$.
\end{abstract}

Do nosso ponto de vista, esta diferença entre crença e conviç̧ão pode formular-se de outro modo. Há em Şartre uma explícita aspiração humana ao divino: «o homem é fun-

(25) Idem, ibidem, p. 197.

(26) F. Jeanson, Sartre dans sa vie, pp. 269-270. 


\section{O Sagrado e o Profano}

damentalmente desejo de ser Deus» (27). A pergunta pelo sentido desta presença obsessiva, que, para mais, aparece escrita já com as letras da nostalgia, so pode formular-se aceitando que essa aspiração é o horizonte em que se inscreve toda a reflexão sartriana - prisioneiro, por isso mesmo, daquilo que se quer(er)ia libertar. É uma presença que Sartre sempre quis (e creu) negar sem se dar conta de que o movimento da negação só pode esboçar-se no mesmo espaço problemático do que se pretende negar. Por isso é que, ao (pensar) encontrar na consciência intencional a via de acesso à compreensão do homem num mundo sem Deus, Sartre transporta a polarização pela plenitude das coisas: os homens, sempre exteriorização de si, porque essencialmente consciência, visam necessariamente o que é em si a partir do nada que são. Por outras palavras: em Sartre, o Outro é sempre exterior; e por isso é que o exercício da liberdade é sempre um acto de conflito ( $\left.{ }^{28}\right)$. A forma do problema de Sartre é, afinal, clássica.

Dá que pensar, portanto, - Derrida lembrou-o com pertinência - que uma obra assim tão (necessariamente) alheada dos grandes textos da contemporaneidade, tenha tido a entusiástica receptividade que se sabe: o dramaturgo não expõe qualquer marca de um Brecht ou de um Artaud, por exemplo; o romancista nada deve a um Joyce; o pensamento filosófico não foi sensível à importância de um Freud, de um Lacan ou de um Bataille (um «místico», dirá), para não referir Heidegger, entre outros. Devemos conceber este alheamento como sinal de uma profunda originalidade, que se originaria a si própria? Talvez seja mais justo sublinhar que, por seu intermédio, Sartre se integra num outro paradigma teórico, precisamente aquele que os nomes citados, entre outros, fizeram entrar em crise. São os termos em que Sartre formula o seu problema que a contemporaneidade reconhece como afastados.

\section{Uma perdição jubilosa}

As implicações da morte de Deus são, no pensamento de Sartre e em alguns seus contemporâneos, essencialmente positivas.

(27) E.N., p. 626.

(2S) «Na ontologia de Sartre, há uma questão de fundo, a da diferença, e uma crise, a da filosofia da identidade», escreve Miguel Baptista Pereira, "O ser e o nada» de J.-P. Sartre no niilismo europeu, Coimbra, 1984, pp. 400-401. 
Desde logo, porque entregam aos homens a possibilidade (a necessidade) de se auto-projectarem, de se realizarem de acordo com o plano que para si próprios traçaram. «Fazer de si próprio uma obra de arte» é uma expressão de Foucault adequada para traduzir a tarefa tipicamente humana, na óptica de Sartre. Não existe um plano que nos tenha pensado, não realizamos (mesmo inconscientemente) um processo cuja Verdade esteja depositada em quaisquer teorias ou sistemas - a cada passo nos escolhemos em situação e nos inventamos como projecto:

«o meu mundo, o meu corpo, o meu meio social, a minha época, o meu passado, a minha raça, sou eu que, em última análise, as valorizo segundo as minhas próprias normas. Em si próprios, eles são absolutamente neutros») $(29)$.

Neutro será o termo? Uma declaração do próprio Sartre («o problema não é o que fizeram de nós mas o que nós fazemos do que fizeram de nós») mostra que tudo isso- mundo, corpo, meio social, passado, etc. - é matéria-prima modelável pelo poder absoluto da minha capacidade, da minha consciência e do meu projecto. Nada constitui limite - interno ou externo - a este poder.

É certo que esta afirmação de autonomia integral pode revestir momentos aparentemente negativos, como o sentimento de desenraizamento: «encontrávamo-nos perdidos num mundo cuja complexidade nos ultrapassava» $\left({ }^{30}\right)$. Aparentemente porquê? Porque se trata de uma perdição jubilosa, de um encontro sem limites nem mediações com a novidade do mundo; esta convicção, evidentemente equívoca (pois, como dirá mais tarde, «pensávamos que o mundo era novo porque nós éramos novos no mundo») ( ${ }^{31}$ ) só é possível pela aguda percepção da decadência dos valores, que tinham organizado o mundo, dos sentimentos que o tinham agregado, das linguagens que o tinham exprimido. Da ruína de um olhar pelo qual as coisas se tornaram visíveis.

Por isso, o gesto de recuperar um olhar imediato, a possibilidade de ter nas nossas imagens das coisas as coisas todas,

(29) Jean-Louis Ferrier, «La pensée anhistorique de Sartre», in L'homme et l'histoire, Paris, 1952, p. 12.

$\left.{ }^{30}\right)$ S. Beauvoir, La cérémonie des adieux, p. 41.

(31) J.-P. Sartre, Situações IV, Paris, 1964, p. 144. Utilizarei, para os volumes desta obra, a abreviatura: $\mathrm{S}$. 


\section{O Sagrado e o Profano}

constituem o eixo em redor do qual se constitui o anarquismo sartriano. Dirá, ao completar setenta anos: «era anarquista sem o saber quando escrevia La Nausée: não notei que o que ali escrevia, podia ter um comentário anarquista, via apenas a relação com a ideia metafísica de náusea, com a ideia metafísica de existência. Mais tarde descobri pela filosofia o ser anarquista que havia em mim» (32).

Anarquismo e autonomia, entendida como auto-criação, implicam-se mutuamente: auto-criação é a capacidade de cada um afirmar a sua diferença relativamente ao que foi ou às imagens que de si construíram, de ser outra coisa e de negar portanto um princípio absoluto, quer dizer que definitivamente explicasse a realidade humana.

A alegria, que percorre a obra de Simone de Beauvoir, em especial $A$ força da idade - e o lugar de destaque que a festa ocupa na sua obra $\left({ }^{33}\right)$ - comemora a entrega das coisas a si mesmas: reconhecimento da liberdade como substância dos homens «não havia, pois, obstáculo para nós, nada nos definia, nada nos sujeitava. As ligações com o mundo nós é que as criávamos» ( $\left.{ }^{34}\right)$; fruição de uma orfandade eventualmente dolorosa mas condição de vida, isto é, de liberdade, tão bem expressa na famosa confissão de Sartre: «houvesse vivido, meu pai ter-se-ia deitado sobre mim a todo o comprimento e ter-me-ia enganado. Por sorte morreu jovem» ( $\left.{ }^{35}\right)$.

A verdade das coisas não está nas coisas nem em qualquer discurso de verdade de que baste apropriar-me. $\mathrm{O}$ sentido das existências não se consegue por um acto de obediência mas resulta de um constante processo de auto-criação. Quando Simone de Beauvoir confessa, como já foi citado, «encontrávamo-nos perdidos num mundo cuja complexidade nos ultrapassava», pressentimos, em primeiro lugar, que já não faz parte dos seus projectos nem cabe no quadro das possibilidades teóricas da época - tal como estas possibilidades e esta época eram pensadas - reduzir essa complexidade a uma lógica universal mas reconhecemos também que se querem criar as tais ligações com o mundo - agora irredutivelmente individuais.

A filosofia contemporânea, como filosofia da contingência, só se poderia formular, ultrapassando a oposição entre

(32) S.-X., p. 144. p. 482 , nt. 6 .

(33) S. Beauvoir, A força da idade, 1960, trad., Lisboa, 1976,

(34) Idem, ibidem, p. 19.

(35) M., p. 11. 
$o$ idealismo e o realismo e afirmando simultaneamente a soberania da consciência e a presença do mundo, tal como ele se nos apresenta. Trata-se, em suma, de subordinar a possibilidade do discurso filosófico à crise da metafísica - pois é esse o problema de Sartre: «falar das coisas tal como as via e isso ser filosofia» $\left({ }^{36}\right)$.

Interessa, por isso, desenvolver uma maior aproximação a esta ideia de contingência, para depois abordar a constituição e as implicações da sua filosofía.

\section{Apresentação da contingência ou o cinema como metáfora}

Recorde-se: «a ausência de Deus devia ler-se por todo o lado. As coisas estavam sós e sobretudo o homem estava só».

«As coisas estavam sós e sobretudo o homem estava só»: a esta solidão das coisas e dos homens, à absoluta des-razão da existência e do mundo, Sartre, recorrendo a um termo clássico, chamou contingência.

É nas salas de cinema que a descobre:

«Pensei sobre a contingência a partir de um filme. Via filmes onde não havia contingência e quando saía encontrava a contingência. É portanto a necessidade dos filmes que me fazia sentir à saída que não havia necessidade na rua» $\left({ }^{37}\right)$.

Sartre é sensível ao contraste. Isto é: à revelação da profunda novidade do cinema. À importância do problema -cinema (ou de um dos aspectos do problema cinema).

Por um lado, ao necessitar de uma certa «comunidade» entre o filme e o espectador, o cinema aproxima-nos da ideia de Unidade: ele exige pelo menos um momento de participação $\left.{ }^{38}\right)$, no qual residirá toda a força mágica do cinema.

Mas é interessante sublinhar um outro aspecto. Há no cinema uma distância intransponível, um espaço negro, que separa o espectador do filme. De certo modo, o cinema exemplifica a impossibilidade do Um.

Seria empobrecer o seu exemplo limitarmo-nos a ver nele a revelação de um dualismo em lugar da instalação de

(36) S. Beauvoir, A força da idade, p. 118.

(37) idem, La cérémonie des adieux, p. 181.

(38) Cf. Edgar Morin, O homem imaginário, 1958, trad., Lisboa. 1970, p. 1811. 


\section{O Sagrado e o Profano}

uma distância no interior de toda a pretensa unidade («Entre duas notas de música existe urna nota, entre dois factos existe um facto, entre dois grãos de areia por mais juntos que estejam existe um intervalo de espaço, existe um sentir que é entre o sentir - nos interstícios da matéria primordial está a linha de mistério e fogo que é a respiração do mundo, e a respiração contínua do mundo é aquilo que ouvimos e chamamos silêncio») (39), da fragmentação de todos os Uns, mesmo (ou principalmente?) da unidade do sujeito.

Compreender até ao fim o modelo-cinema é compreender a inultrapassável distância jamais preenchida pela transparência de um olhar. É no exercício do olhar, mas vivendo a distância que o separa da Necessidade, que a contingência se revela. Dela Sartre sente-se afastado: não das imagens, claro, ou das sombras que preenchem a brancura do écran. Mas da organização, das relações necessárias que ligavam as imagens do filme. Ao mesmo tempo, Sartre descobre a Necessidade e a distância dela.

Distância da Necessidade. Ou, em palavras mais ajustadas ao vocabulário de Sartre deste período, incompletude. $\mathrm{O}$ homem é ser incompleto. Vejamos uma das passagens mais expressivas em que Sartre apresenta a sua doutrina da falta.

Escreve:

«Uma falta supõe uma trindade: o que falta (manquant), aquilo a que falta o que falta ou existente, e uma totalidade que foi desagregada pela falta e que seria restaurada pela síntese do faltante e do existente: é o faltado ('le manqué')» (40).

Trata-se, como é claro, de fugir do dualismo. Em-si e para-si não se encontram face-a-face:

«o Para-si e o Em-si são reunidos por uma ligação sintética que não é outra senão o Para-si. Com efeito, o Para-si não é outra coisa senão a pura nadificação do Em-si; é como um buraco de ser no seio do ser» $\left({ }^{41}\right)$.

$\mathrm{O}$ decisivo, porém, não reside aqui. $\mathrm{O}$ que devemos reter é a presença de uma totalidade em função da qual, ou a partir da qual, Sartre organiza o seu pensamento. É o duplo estatuto

(39) Clarice Inspector, A paixão segundo G. H., Rio de Janeiro, 7. ${ }^{\text {a ed., }}$ 1979, p. 94.

(40) E.N., p. 125 , subi. meu.

(41) E.N., p. 681. 


\section{Gestos \& Fragmentos}

dessa presença, que colocamos no centro destas páginas: por um lado, condição definitivamente irrecuperável; por outro, fascínio (obsessão) constantemente presente. É da impossibilidade definitiva da síntese entre as duas regiões do ser que Sartre retirará o tema do fracasso; por isso mesmo, ele só tem sentido para a posição prévia da existência-(na)-totalidade como ideal: «é este ideal que se pode chamar Deus» $\left.{ }^{42}\right)$. Vale a pena citar integralmente a passagem em questão:

«é enquanto ser que é o que não é e que não é o que é que o par a-si projecta ser o que é; é enquanto consciência que ele quer ter a impermeabilidade e a densidade infinita do em-si; é enquanto nadificação do em-si e perpétua evasão da contingência e da facticidade que ele quer ser o seu próprio fundamento. É por isso que o possível é projectado em geral como o que falta ao para-si para se tornar em-si-para-si; e o valor fundamental que preside a este projecto é justamente o em-si-para-si, quer dizer o ideal de uma consciência que seria fundamento do seu próprio ser-êm-si pela pura consciência que tomasse de si própria. É este ideal que se pode chamar Deus. Deste modo, pode dizer-se que o que melhor torna concebível o projecto fundamental da realidade humana é que o homem é o ser que projecta ser Deus. Quaisquer que possam ser em seguida os mitos e os ritos da religião considerada, Deus é primeiro 'sensível ao coração do homem' como o que o anuncia e o define no seu projecto último e fundamental. E se o homem possui uma compreensão préontológica do ser de Deus não são nem os grandes espectáculos da natureza nem o poder da sociedade que lha conferiram: mas Deus, valor e objective) supremo da transcendência, representa o limite permanente a parcir do qual o homem se faz anunciar o que é. Ser homem é tender a ser Deus; ou se se preferir, o homem é fundamentalmente desejo de ser Deus» $\left({ }^{43}\right)$.

Lemos nesta página de excepcional clareza, ainda que não seja a clareza que Sartre poderia querer imprimir, a matriz de todo o desejo de objecto absoluto. É justamente pela admissão deste desejo-de-objecto-absoluto que conferiria sentido pleno às visadas parciais da vacuidade da consciência, que nos sentimos distanciados de Sartre.

Dir-se-á que, precisamente, Sartre nega a possibilidade desta síntese; que procura fundar um ateísmo integral. É certo. Mas o que aqui se sublinha é que a sua obra, organizada em termos de negação e não de diferença (reencontramos, neste

(42) E.N., p. 626.

(43) E.N., p. 626. 
ponto, a crítica de Nietzsche à dialéctica) ficou encerrada no espaço teológico. São palavras de Maurice Blanchot que agora nos auxiliam:

«na medida em que transpomos o divino não o chegamos a anular - porque anulá-lo não pode (e isso é o essencial) consistir em negá-lo, mas em substitui-lo por uma possibilidade ainda não percebida, isto é, abrir uma dimensão radicalmente outra» $\left({ }^{44}\right)$.

Ora, esta dimensão radicalmente outra não pode consistir em substituir o fracasso de não (poder) ser Deus pelo fracasso de não (poder) ser o em-si, pois o movimento que envolve os homens, num e noutro sentido, é essencialmente o mesmo.

Estes pressupostos decidiram antecipadamente o resultado. A incompletude como tensão para uma completude que a desfaria, preenchendo-a, é o esquema mais geral de toda a tentação utópica: o futuro, como diferença absoluta, traria a homogeneidade reconciliadora dos homens consigo próprios.

Não é fortuito que, descoberta a importância da dimensão histórica, Sartre seja sensível a esta dimensão utópica e a tenha perseguido da União Soviética à China, de Cuba a Portugal, passando pela importância histórica e filosófica da dissidência para fixar-se (provisoriamente) num neo-anarquismo ainda messiânico $\left({ }^{45}\right)$ e, por isso, incapaz de elaborar produtivamente uma aquisição contemporânea essencial: a crise das ideologias do futuro, a crise das utopias.

Para esta crise, que agora não cabe explorar, terá contribuído a convicção de que à falta de objecto absoluto, irrecuperável, não corresponde $\mathrm{o}$ vazio absoluto. A elevação da categoria de jogo a símbolo do mundo (Eugen Fink) $\left({ }^{46}\right)$ e a tese da história como processo sem Sujeito(s) nem Fim(ns) (Louis Althusser) ( ${ }^{47}$ ) conferem ao utópico uma importância fantasmática ou estética e abrem a possibilidade de um pensamento, que se não desenvolva a partir do primado do Um.

Como escreve Maurice Blanchot, «a insuficiência não se conclui a partir de um modelo de suficiência. Ela não procura

(44) Maurice Blanchot, «O ateísmo e a escrita. O humanismo e o grito», Cadernos O tempo e o Modo, Lisboa, 1963.

$(45)$ Cf. Maria Manuela Saraiva, «O testamento de Sartre», Biblos, vol. LVI, 1980, pp. 213-236, esp. p. 216.

(46) Eugen Fink, Spiel ais weltsymbol, 1960, trad, franc. Le jeu comme symbole du monde, Paris, 1966.

${ }^{(47)}$ Louis Althusser, Réponse à John Lewis, Paris, 1973. 
o que lhe ponha fim mas antes o excesso de uma falta que se aprofundasse à medida que se preenchesse» $\left({ }^{48}\right)$.

Não há mediação absoluta: há sempre o excesso, e o «excesso não é o demasiado pleno, o super-abundante», escreve ainda Blanchot: «é a exigência jamais satisfeita da insuficiência humana» $\left({ }^{49}\right)$.

Defender que «o desejo já não é desejo de qualquer coisa; tensão para um objecto que falta e de que se sente sempre a falta para que o desejo, a transcendência e as crenças vivam; não é produzido por uma incompletude» $\left.{ }^{50}\right)$ é aproximarmo-nos de um pensamento que já se não elabora a partir do ponto de vista do primado do Um.

A perplexidade que invade o leitor de L'Être et le Néant recorta-se na sombra de toda a filosofia da consciência. No presente trabalho encontra-se a notícia desta perplexidade e pretende-se esboçar um movimento que pense a distância de Sartre, quer dizer, em que a distância da filosofia da consciência seja pensada.

$\mathrm{O}$ que implica também um movimento na filosofia. Como escreveu Althusser, «a filosofia não existe.... senão com a condição de poder oferecer ela mesma um discurso racional puro», discurso esse que cumpre numa tarefa precisa, «a de dizer a Verdade sobre todas as práticas e ideias humanas», pois a «filosofia considera, na sua convicção historicamente íntima, que ninguém nem nada pode falar em seu nome e se ela não existisse ao mundo faltaria a Verdade» $\left({ }^{51}\right)$.

E se a Verdade, ou a sabedoria, dissessem hoje ao filósofo (suponhamos que a Verdade é uma mulher, como sugeria Nietzsche), o mesmo que Mavi diz ao seu amante: «Diz-me 'amo-te ${ }^{7}$ e depois diz-me o que quer dizer amar»? Em Identificação de uma Mulher, de Antonioni.

Se o cinema é uma actividade inteiramente projectiva (52) cuja natureza se capta unicamente numa relação solitária ( ${ }^{53}$ ) impõem-se duas conclusões: primeiro, a experiência

(48) Maurice Blanchot, La communauté inavouable, Paris, 1983,

(49) Idem, ibidem, p. 20, nt. 1.

${ }^{50}$ Jacques Donzelot, «Uma anti-soeiologia», in Capitalismo e Esquizofrenia (Dossier Anti-Édipo), org. Manuel Maria Carrilho, Lisboa, 1976, p. 158. 1976, p. 14.

(51) L. ALhusser, La transformación de la filosofia, Granada,

(52) Roland Barthes, Le grain de la voix, Paris, 1981, p. 18.

(53) Idem, ibidem, p. 18. 


\section{O Sagrado e o Profano}

de que o cinema é metáfora, é irredutivelmente individual; depois, esta experiência é, a um tempo, a da Necessidade como imaginário e a da contingência como realidade. É no espaço aberto pela polaridade Necessidade/contingência que Sartre formula o seu problema e procura os meios de $o$ resolver.

Recebemos a mesma ideia, com toda a nitidez, de uma concepção de homem:

«era ao mesmo tempo um ser perdido no mundo [perdição significa aqui contingência] e, por consequência, cercado de mundo por todos os lados, como que aprisionado no mundo. E ao mesmo tempo um ser que podia sintetizar este mundo e vê-lo como seu objecto, estando-lhe face a face e fora. Já não estava dentro, estava fora. É esta ligação do fora e do dentro que constitui o homem» $\left({ }^{54}\right)$.

O momento sintético, cuja possibilidade demonstra a diferença essencial do modo-de-ser dos homens e do modo de ser das coisas, pressupõe o primado do olhar. Pelo menos é significativo que a sua imagem seja esta. Sartre exemplifica:

«Estava em Tours, por exemplo, sentado a uma mesa de café, e ao mesmo tempo, sem sair de Tours, sem me mexer, mas recusando ser um objecto simplesmente definido pelo meu estar aí, podia ver o mundo como uma síntese, quer dizer como a totalidade dos objectos que me envolviam, que eu via, e para além de outros objectos, os horizontes, como diz Heidegger. Em suma, captar o mundo como o conjunto destes horizontes, sendo constituído igualmente por objectos» $\left({ }^{55}\right)$.

Desenraizados (da necessidade) do mundo, transcendentes ao mundo, só pelo olhar os homens podem captá-lo: o olhar aparece como o modelo da relação que resiste sob a crise de todas as mediações.

«Penso com os olhos», anota Sartre (56) e esta brevíssima fórmula condensa toda a importância (e o tipo de importância) concedida ao olhar.

Que mesmo a sua autobiografia seja um cruzamento de olhares, um desencontro de olhares, é um aspecto que não deve, também, passar em claro.

(54) S. Beauvoir, La cérémonie des adieux, p. 547.

(55) Idem, ibidem, p. 548.

(se) C.G., p. 27. 